\title{
"Standing humbly in the ante-chambers of Clio": the rise and fall of Union War Histories
}

\section{Jeffrey Grey}

The Second World War was a titanic struggle which involved the Dominions of the 'old' Commonwealth in the British and allied war effort from the war's very beginning. Each Dominion took a different role in the war - Australia alone was heavily involved in the Pacific war against the Japanese, for example, while Canadians, New Zealanders and South Africans all fought in the European Theatre of Operations, and New Zealanders and South Africans fought in the Western desert as well - and the domestic reactions and pressures on national governments likewise differed in each case. Homogeneous Anglo-Celtic societies in Australia and New Zealand experienced few internal rifts over the fact of involvement in the war, while in both Canada and South Africa the politics of divergent linguistic communities restricted the options available to national governments when it came to decisions governing their national contributions to a 'British' war effort. In the war's aftermath the place which the war had occupied in national life was by turns, solidified, contested, appropriated by different groups in a manner similar to that which had occurred after the First World War, and with some of the same outcomes.

After the Great War all the empire armies had looked to the production of national official histories that would teach the lessons of the late war and explain the sacrifices that the population had been called on to make. The results were generally pretty mixed. New Zealand produced four volumes on a semi-official basis, which is to say that a number of army officers were given access to records in order to write the volumes in their own time. In Canada, the creation of an Historical Section and the appointment of an official historian, Colonel J. Fortescue Duguid, resulted in the publication of a single volume in 1938 that dealt with Canadian involvement only to September 1915. Neither outcome is now regarded as satisfactory, and Duguid's effort was thought to be inadequate even at the time; it was supplemented by a single volume history of the Canadian Expeditionary Force published in 1962. India, of course, published no separate history of the Indian military contribution to the Empire's war effort.

Australia and Britain both produced extensive, multi-volume histories through the 1920s and 1930s, although the two series were very different from each other. The British series was edited, and largely written, by Brigadier Sir James Edmonds, and conformed to the traditional notion of the didactic General Staff 
history produced with the needs of Staff College instruction in mind. It was not designed for a general readership, and Edmonds famously (or notoriously) rejected the idea that the history might explain to ordinary readers the shortcomings in the British conduct of the war ('I had always space and the views of my comrades to consider', as he noted on one occasion to Liddell Hart). As is also well known, the casualty figures used in the volumes dealing with the offensive on the Somme in 1916 were almost certainly manipulated in order to give a more favourable impression of the process of attrition against the German forces in France in the course of that year's fighting. The Australian history, edited by C.E.W. Bean, had exactly the opposite purpose. Bean had conceived his history while serving with the Australian Imperial Force overseas as its official correspondent, and had decided that the history should explain to Australians the stern tests and heavy sacrifices which their men had faced in theatres of war on the other side of the world. Where Edmonds dealt largely with command echelons and rarely dipped below battalion or brigade in his narrative of operations, Bean took as his focus the ordinary soldiers and junior officers, and wrote from the perspective of the forward trenches. The result, in his own words, was 'democratic' history of a kind that no other national official history sought to emulate until after the Second World War.

South Africa's approach was different again, though closer to that of the Canadians and New Zealanders than of the British and Australians. The noted British author John Buchan was asked by Smuts to write an account of the South African Brigade in France, and this appeared in 1920. Agar-Hamilton thought it 'limited in scope and [suffering] from lack of specialized knowledge', while the general lack of writing on South Africans on the Western Front he thought was explained by the 'grim fact that the casualties of the First Brigade carried off many who might otherwise have put down a record for posterity'. 'The South African military, seeking something more didactic in purpose and extensive in coverage, authorized the production of an 'official history' of the Union and the Great War, published in 1924. Although it is usually ascribed to Major J.G.W. Leipoldt, and he indeed wrote a number of sections, a substantial part of the book was written by Brigadier General J.J. Collyer, who was in fact given overall responsibility for its appearance. ${ }^{2}$ Inadequate or otherwise, Leipoldt adapted and incorporated a large part of Buchan's account, for which the latter received a fifty guinea fee. Completed in late 1921, publication was delayed for two years by concerns over printing costs. ${ }^{3}$ Collyer later wrote two accounts of South African campaigning in German

I Minute, Agar-Hamilton, 28 Dec 1943. Union War History (UWH) administrative files, box 9, PMH51. Directorate Documentation Services (DDS), Pretoria.

Minute, Brigadier A.J. Brink to Major J.G. Leipoldt, 1 Feb 1921; minute, Secretary of Defence to Brigadier J.J. Collyer, 30 Mar 1920. Chief of the General Staff Group 2, box 147, CGS276. DDS (P). 
Southwest Africa (1937) and German East Africa (1939), but these were little more than narrow military chronicles. ${ }^{4}$

Only the Australians utilized the same approach to writing the official history of the Second World War that they had adopted for the history of the First. The next official historian, Gavin Long, was the personal nomination of his predecessor, Bean. The authorities in both Canada and New Zealand were persuaded during the war that the efforts and sacrifices of another generation of their citizens deserved a more sophisticated and complete handling than had been the case previously, and in both instances the histories were placed in the hands of soldierscholars, Colonel C.P. Stacey and Major General H.K. Kippenberger respectively. The British modified the 'General Staff' history to some extent, and while it continued to focus on the higher command echelons the results were generally more open and more critical, on a few occasions blisteringly so. This effort was overseen by a civilian academic, Professor J.R.M. Butler, rather than a general, although most of his authors and staff narrators were in fact retired senior officers. The great efforts that India made in the defeat of the Axis were recognized through an Indian official history, one whose purpose was strengthened by independence though not by partition. ${ }^{5}$ For reasons of its own, following this war Northern Ireland also produced a separate official history.

In South Africa there was a strong view, at least in some quarters, that the country's war effort this time around should be documented properly during the war with the intention of producing some form of serious historical account later. Official support for such an undertaking was first provided by Major General A.J. Brink, Deputy CGS, in August 1940. 'It is necessary', he wrote, 'to keep a comprehensive written and pictorial record of events immediately prior to and since the declaration of war', and to this end an Historical Records Committee was set up in November. ${ }^{6}$ An historical sub-section was created in early 1941 within the Directorate of Military Intelligence, and Captain J.A.I. Agar-Hamilton was appointed to head it. This was the same route that the other Dominions followed: creation of a records section followed later by the formal appointment of an individual as official historian, either during the war itself or shortly after its conclusion. C.E.W. Bean had gone down the same path during the First World War. By the middle years of the war there were three separate areas collecting materials documenting the war effort: Agar-Hamilton's group in DMI, the South African War

Ian van der Waag, 'The Marriage of Clio and Mars: The Practice of Record Preservation and the Writing of History within the SADF', unpublished manuscript, 1993, p 82-83.

The Indian official history began during the war under British auspices as an 'all India' undertaking. With independence and partition the history was taken over by the newly independent Indian government, and although for some time it carried reference to Pakistan in its formal title, Pakistan played no part in its writing or production.

Minute, Brink to all Directorates, 26 Aug 1940. UWH administrative files, box 1, C304727. DDS (P). 
Diary Section, and the Medical History Section. Collecting records was one thing; the quality of what was collected was quite another. As early as September 1941 Agar-Hamilton advised his superiors that inadequate records would lead to an inadequate history, and directed the Army's attention to both the efforts of the $\mathrm{SAAF}$ and of the Australian Historical Records and War Diaries Section which, as part of AIF Headquarters in the Middle East, was able to take a direct interest in the keeping and forwarding of war diaries.?

Agar-Hamilton worked assiduously during the war to ensure that all the pieces were in place to bring about a worthy official historical effort. Born in Cairo to a colonial civil servant in 1895, he migrated to South Africa as a child in 1906 and studied at the Transvaal University College, graduating in 1914. He undertook further study at Oxford, and returned to South Africa in 1923 to an academic post at the University of Pretoria which he held until 1940 . His early published work dealt with Voortrekker policy towards the native people, in which he revealed himself a critic of $19^{\text {th }}$ century Afrikaner institutions and an opponent of Afrikaner nationalism. From his position within the General Staff he kept up a regular flow of memoranda to his military superiors, several of who agreed with his position and facilitated his activities. In January 1943 he recommended to the CGS the establishment of an Historical Advisory Committee within the Union Defence Force, and this was established in March although it did not meet until October. In its original form it comprised Professor Leo Fouche (chair), Lieutenant Colonel Graham Botha, the Union Archivist, and Lieutenant Colonel E.G. Malherbe who had become Director of Military Intelligence, and hence Agar-Hamilton's boss, in early $1943 .{ }^{8}$ Fouche had been forced to resign as professor at the University of Pretoria in 1934 because of his opposition to Afrikaner nationalism and teaching practices there, and he had accepted a chair at the University of the Witwatersrand. He left this in 1942 to become Chairman of the South African Broadcasting Corporation. His earlier writing on the 1914-15 rebellion had marked the beginning of his estrangement from the pronounced nationalistic spirit', and he was a personal friend of Smuts; Agar-Hamilton had been a protégé. ${ }^{9}$

Even before this committee had convened, Agar-Hamilton had drafted his conception for the official history and forwarded it to his superiors. At this stage, the beginning of 1943, he envisaged a two-fold approach: a popular single volume treatment aimed at a general readership, and a collection of more technical

Minute, Agar-Hamilton to Deputy Director of Military Intelligence, 26 Sep 1941. UWH administrative files, box 3, PMH28. DDS (P).

Minutes, Staff conference, 25 Aug 1943. UWH box 55, PMH1/1: memorandum, Fouche to Smuts, 2 Oct 1945, UWH administrative files, box 9, PMH51, part 1. DDS (P).

F.A. Mouton, 'Professor Leo Fouche, the History Department and the Afrikanerisation of the University of Pretoria', Historia, 38:1, May 1993, p 62. 
monographs written by and for those with expertise in various fields. ${ }^{10}$ The popular volume needed an author who could tailor his writing to that audience, and initially Agar-Hamilton suggested Professor Eric Walker, then Professor of Naval and Imperial History at St Johns College, Cambridge and formerly professor of history at Cape Town. 'His writings display a combination of accurate scholarship with the "grand style" of writing, which should prove admirable for some aspects of the Official Histories', wrote Malherbe." The intention was to make Walker the 'editorin-chief ' of the series, but ill-health forced him to withdraw in July 1944. The matter was therefore allowed to lie for the time being.

Agar-Hamilton certainly did not rest, and in the last year of the war became concerned that the advent of peace would reorder national priorities to the disadvantage of the official history. 'From the national point of view', he wrote in August 1944,

the work of the UDF Official History will go on long beyond the close of hostilities. The failure to do justice to the achievements of the South Africans who took part in the last war was a serious loss, and deprived the South African national tradition of an element of which it could have had every reason to be proud. It is the repetition of this failure that [we] are seeking to avoid by building up a strong historical department. ${ }^{12}$

He had intended the advisory committee be 'the first step' towards the coordination of a comprehensive UDF history, and that the formulation of policy concerning that history, the fashioning of a structure and the recruitment of suitable staff should be undertaken by the editor-in-chief, which position was vacant. '[A] beginning should be made with the preliminaries of the History before it is too late', he wrote in April 1945, not least because he feared that the Army itself might take too close an interest and 'decide to write the history in the way they want it written. The historian must be independent of the Department of Defence'. ${ }^{3}$

At this point Agar-Hamilton still conceived of a two part history, what he now termed a 'people's history' and a 'military college' history. ${ }^{14}$ The organization intended to produce these works had become rather more grand. Beneath a civilian editor-in-chief, Agar-Hamilton and the advisory committee recommended two assistant editors, responsible for the UDF and the civil histories respectively. These

Minute, Agar-Hamilton to DMI, 15 Jan 1943. UWH box 55, PMH1/1. DDS (P).

Minute, Malherbe to DCGS, 9 Feb 1944. Ibid.

Letter, Agar-Hamilton to L.C.F. Turner, 17 Aug 1944. UWH administrative files, box 9, PMH51. DDS (P).

Minute, Agar-Hamilton to Director, Staff Duties, 23 Apr 1945; letter, Agar-Hamilton to Botha, 24 Nov 1944. Ibid.

Minute, Agar-Hamilton to DSD, 10 Apr 1945. UWH box 55, PMH1, volume 2. DDS (P). 
would administer records and narrative sections, the latter designed to produce carefully researched, fully documented written accounts of all phases of the ground, air, naval, medical and civilian efforts during the war. Production of the narratives would clearly involve a sizeable staff, and Agar-Hamilton was at pains to stress that this would be a temporary measure; 'as soon as their work is done, it will be possible to dispense with this large establishment and to undertake the publication of the Official History at a much slower tempo with a very much smaller staff' ${ }^{15}$ The popular history, on the other hand, he regarded as a matter of urgency, rightly sensing that the authorities would not continue to outlay resources indefinitely unless there were early results. For the two key posts in this structure, the advisory committee recommended Major L.C.F. Turner as chief narrator for the UDF history, and Lieutenant Colonel J.A.I. Agar-Hamilton as editor-in-chief. ${ }^{16}$

In its recommendation supporting Agar-Hamilton for the top position the committee wrote that it knew of no-one more suitable.

$\mathrm{He}$ is not only the most experienced officer in the field, but his standing as a scholar and historian is such that the Committee, after careful consideration of the qualifications of all other likely candidates, confidently recommends him for the post.

The confidence, it seems, was not shared by all concerned. In October 1945, with the recommendation not yet acted on, Agar-Hamilton became aware (how is no longer clear) that Professor Michael Roberts of Rhodes University was under active consideration for the post of editor-in-chief. Roberts had served as a junior officer in Agar-Hamilton's section earlier in the war, and the latter clearly disliked him. Supported openly by Botha and the rest of the advisory committee, Agar-Hamilton asked that his name be considered for the post and that, if he was unsuccessful, advised that he would resign and return to his teaching position at the university. In the circumstances, his confidential evaluation of Roberts' suitability for the position was scarcely even-handed. [He] lacks application', he wrote,

And is either incapable of, or not attracted by continuous work... He is lacking in judgment, and shows a tendency towards irresponsibility. Further, he rather prides himself on his detachment from South African affairs, and at his University leaves South African history entirely to others. ${ }^{17}$

Whether he would have been interested in the position is moot; Roberts went on to a distinguished career as Professor of History at Rhodes followed by twenty

Ibid.

Minute, Fouche to acting Minister for Defence, 15 May 1945. UWH administrative files, box 9, PMH51. DDS (P).

Confidential report, 3 Oct 1945. UWH administrative files, box 12, PMH51/G. DDS (P). 
years at Queen's University, Belfast as the foremost scholar of early modern Sweden and the age of Gustavus Adolphus.

The threat to his position thus eliminated, Agar-Hamilton began to define the functions of his position and recruit his senior staff. At the end of the war responsibility for the Union War Histories, as the project was now designated, had been moved from the Directorate of Military Intelligence to the office of the prime minister. In his remaining years in office, Smuts took a keen personal interest in their work, and this fact undoubtedly assisted Agar-Hamilton to overcome resistance to his requests in other government agencies, not least within the Union Defence Force. As he reminded the deputy CGS in early 1946, he had accepted the position

conditional on adequate powers being attached thereto, and particularly the right of access to any necessary documents. The two Assistant Editors designate have made it quite clear that their acceptance of the posts offered to them is dependent on the possession by the Historical Section of reasonable powers of investigation and collection of evidence.

I have suggested that the simplest way of deciding what these are, is to confer on the Editor-in-Chief, who will accept the responsibility, the same powers as are exercised by the British Cabinet Historical Section. These can be determined in detail at a later date, and it would be unreasonable to expect any more. At the same time I would not undertake the work with less. $^{18}$

Over time he and his staff were to receive generous cooperation in matters of access, both within South Africa and elsewhere within the Commonwealth. Finding and keeping the resources necessary to support the writing was another matter.

The South African organization for producing the histories was modest by comparison with all the other Dominions, and finding and keeping good staff was a constant problem. Turner had been demobilized in Britain at the end of the war, and although Agar-Hamilton had asked for his services in the middle of 1945, in January 1946 he was still petitioning the Adjutant General's Branch to be feally helpful and bring him back to South Africa to duty with the least possible delay and a minimum of irrelevance'. ${ }^{19}$ Turner was 'a trained historian who has specialized in military history, for which he has displayed uncommon enthusiasm', and his services were eagerly awaited although in May 1946 the position he was to occupy had not yet been approved by the civil service authorities. ${ }^{20}$ With pressure to reduce the armed forces and defence expenditure at the war's end, there was considerable uncertainty about the future of Union War Histories, while most of the senior staff, and not a

Minute, Agar-Hamilton to DCGS, 24 Apr 1946. Ibid.

Minute, Agar-Hamilton to DDMT, 24 Jan 1946. UWH administrative files, box 26, PMH107/A/1. DDS (P).

Letter, Agar-Hamilton to Brigadier H.B. Latham, Cabinet Historical Section, London, 18 May 1946. CAB103/142. PRO. 
few of their juniors, had teaching posts to which they had to return within six months of the end of hostilities. ${ }^{21}$ In February 1946 it was decided that all posts would be civilian ones, although the establishment was not authorized until March 1947. Staff turnover remained a problem for several years; Axelson, the original choice as assistant editor for the military series, left in 1949 to work in the Central African Archives in Rhodesia and was replaced by Turner. The key players among the senior appointments - Agar-Hamilton, Turner, H.R. Gordon-Cumming and J.E. Betzler - were all on the staff by early 1947. Turner was to leave for a university post in Australia in 1956 and Betzler died of a heart attack while supervising the winding up of the project in $1960 .^{22}$ The civil history collapsed through lack of government interest after 1948, while the planned medical history simply never eventuated.

Such resources as Agar-Hamilton was able to obtain, then, were concentrated on the production of the military volumes. Three were published during the life of the project: Crisis in the Desert, May-July 1942 (1952), The Sidi Rezeg Battles 1941 (1957), and War in the Southern Oceans (1961). Given the modesty of the overall undertaking this represented a creditable rate of production (although the critics in all the countries concerned were always of the view that good history can be written for next to nothing in next to no time). As he developed a personal relationship with his opposite numbers around the Commonwealth, AgarHamilton was constantly reminded of the paucity of his own resources when contrasted with the approach taken elsewhere. Following the meeting of AngloAmerican historical sections in Washington DC in February 1948, he wrote of 'the considerable scale on which the participating countries - with the exception of the Union of South Africa - have planned their official histories, the confidence reposed in their chief historians, and the ready assistance rendered by their civil and military administrations'. ${ }^{23}$ The Australians based a representative in London in order to examine and copy records there, while Agar-Hamilton had to request authority to pay for copies of the records he needed, and relied on the willingness of the British to retrieve the materials on his behalf. Kippenberger in New Zealand enjoyed strong backing from the Cabinet, and was able to report in early 1947 that the government had granted him another 60,000 to underwrite the production of twenty volumes of

21 Memorandum, Fouche to Smuts, 9 Oct 1945. UWH administrative files, box 9 , PMH51. DDS (P).

Minute, Brigadier S.J. Joubert, acting Adjutant General to Agar-Hamilton, 19 Apr 1947. DGD Branch, box 100, 33/4; letter, Agar-Hamilton to Major General H.K. Kippenberger, 7 Dec 1949. UWH administrative files, box 48, PMH206. DDS (P).

Agar-Hamilton, report on Washington conference. UWH administrative files, box 8 , PMH44. DDS (P). 
individual unit histories. ${ }^{24}$ In South Africa, the Treasury had not yet authorized any publication at the beginning of $1950 .^{25}$

By 1950 Agar-Hamilton had abandoned his original scheme for a popular history, almost certainly because of the resource restraints under which he operated. In its place, he resolved to produce treatments of particular 'phases' of South Africa's war and production of the land, sea and air narratives was directed to this end. ${ }^{26}$ As he explained to an official in London,

With our very small staff, and the difficulty in replacing 'natural wastage', we have not yet arrived at the stage of publication. We have been collecting our own material and building up an archives establishment, which takes time, particularly as our view of the nature of the history is not quite so much restricted to official documents as the United Kingdom conception must be. We have also been preparing a number of narratives, of varying degrees of completeness, which are clearing the way and setting the scene for the publications when we settle down to them. ${ }^{27}$

The staffing situation did not improve. In 1950 the chairman of the Advisory Committee, now Professor H.B. Thom following the death of Fouche the previous year, attempted to intervene through the Public Service Commission, to little avail. Because Agar-Hamilton's was the only permanent position, all the rest being contracted, the male staff in particular tended to accept any reasonable offer of permanent employment when it came along. (Agar-Hamilton, a confirmed bachelor all his life, wrote that the lack of job security 'does not affect thewomen so much, as they all look forward to getting married - poor things!). ${ }^{28}$ By late 1954 , with a volume published to considerable acclaim and work well advanced on another, it remained the case that 'the good men are always being snapped up by someone who can give them permanent employment'. ${ }^{29}$

By the 1950s there were more serious threats to the work of the Union war Histories section than those posed by an unsympathetic civil service and the

Letter, Agar-Hamilton to Latham, 13 Dec 1947. UWH box 393, PMH19, volume 2; letter, Kippenberger to Agar-Hamilton, 17 Jan 1947. UWH administrative files box 12, PMH51/H4. DDS (P).

Letter, Agar-Hamilton to Latham, 17 Jan 1950. CAB103/523. PRO.

Letter, A.B. Acheson, Cabinet Office to Agar-Hamilton, 20 Mar 1950. UWH box 393, PMH19 volume 2. There are short reports on the state of the civil and military histories, together with a list of narratives completed, attached to this letter.

Letter, Agar-Hamilton to Acheson, 4 Apr 1950. CAB103/523. PRO.

Letter, Agar-Hamilton to Thom, 30 Aug 1950. UWH administrative files box 9 , PMH51 part 2. DDS (P).

Letter, Agar-Hamilton to Colonel C.P. Stacey, Ottawa, 28 Oct 1954. UWH administrative files box 12, PMH51/H2. DDS (P). 
existence of more attractive employment options elsewhere. When Smuts was defeated in the elections of May 1948 the official history lost both a friend and a patron. Agar-Hamilton had prefigured such an outcome as early as 1944 , when he noted that

a change of government would bring in a body of people who have the best of reasons for forgetting about the war and seeing to it that everybody else forgets as soon as possible. They are clever enough not to stop the history altogether, but would see to it that it is completely unsatisfactory. ${ }^{30}$

In this he was correct. As he further noted to the American historian, Kent Roberts Greenfield, in October 1948, 'the cognoscenti have suggested that political changes might be expected to bring our labours to a speedy end, but nothing has happened as yet'. 31 The attacks, when they came, were indirect, designed to marginalize the undertaking and make its task more difficult. Thus in December 1948 Union War Histories was moved out of the Union Building and into a ramshackle building at 724 Government Avenue, out of sight and well away from the sort of access it had enjoyed under Smuts. In March 1949 Malherbe, who was acting as chairman of the Advisory Committee following Fouche's recent death, was summarily removed at the direction of the prime minister, Malan. This occasioned some comment in the English-language press, which wondered whether this was an attempt by the Nationalists to impose a 'neutral' position on the histories.

For some years Agar-Hamilton's little group was largely left alone, presumably because they just did not matter enough when there were more important tasks awaiting those bent on the radical 'Afrikanerising' of South Africa and its institutions. Nonetheless, they lost the sense of certainty with which their activities had been imbued in the years immediately after the war: 'if we get a complete documentation, that might conceivably be enough for the present', wrote Agar-Hamilton in 1952, before further suggesting that the actual histories might have to be written by others at a later date. ${ }^{32}$ The changes certainly led Turner, the most able of the senior staff, to leave South Africa for good in 1956, and with him meant much of the energy and intellectual edge which marked the section's earlier work; Agar-Hamilton described it as 'the gravest possible loss'. ${ }^{33}$ The Editor-inChief himself formally retired in August 1955, but remained on to oversee the production of The Sidi Rezeg Battles. Clearly concerned about the future of the section with so much still to be done, Agar-Hamilton and Thom saw the prime

30 Letter, Agar-Hamilton to Botha, 24 Nov 1944. UWH administrative files box 9, PMH51. DDS (P).

31 Letter, Agar-Hamilton to Greenfield, Washington DC 8 Oct 1948. UWH administrative files box 49, PMH207. DDS (P).

32 Letter, Agar-Hamilton to Acheson, 16 Apr 1952. CAB103/523. PRO. (P). 
minister, Strijdom, in March 1956 about the official history. 'He was most polite', as Agar-Hamilton related to Kippenberger, 'but a poker face was as near as we got to conducting that particular game of skill. (As a matter of fact, the omens are really quite favourable.)'. The reference to poker recalled advice that his New Zealand counterpart had offered on handling one's prime minister - 'he played poker with his regularly, and that raised a delightful picture in my mind of myself playing poker with Strijdom' ${ }^{34}$ But his forecast was accurate, and following the representations made to him the prime minister approved an extension of the life of the official history to July $1959 .{ }^{35}$

The Sidi Rezeg Battles sold poorly, which prompted Betzler, who had assumed the day-to-day running of the section, to cut the manuscript of War in the Southern Oceans quite severely in order to ensure its publication under the gaze of a hostile Treasury. 'I personally think the public is getting tired of war books', he wrote to Oxford University Press's South African office, a view echoed by AgarHamilton, who agreed that 'the market is surfeited with sham war books . . . and serious stuff simply does not sell, ${ }^{36}$ Declining sales and few reviews further endangered the continuation of the project, although in mid-1958 Betzler believed that 'we have more or less binding assurances that some modus vivendi will be found to allow us to carry out our program'.

Strijdom died in office in August 1958, and with the passing of this unlikely defender of the Union War Histories went any realistic chance for the completion of the official history as Agar-Hamilton and others had envisaged it during and after the war. In August 1959 it was announced that the section would close in June 1960 'apparently for economy reasons'. The announcement, noted a British diplomat in Pretoria,

has provoked criticism in the English-speaking section of the press in particular and suggestions have been made for getting the job finished by some unofficial organizations or else by their contributing towards the cost. But there is no indication yet whether or not some such substitute arrangement will be made. ${ }^{37}$

The Council of Corps, Regimental and Kindred Associations of South Africa and the South African Ex-Services National Council, orchestrated by Lieutenant

Letter, Agar-Hamilton to Latham, 10 May 1957. UWH box 363, PMH204 volume 8. $\operatorname{DDS}(\mathrm{P})$.

Annual report on Union War Histories section, 1956. UWH administrative files box 47, PMH203. DDS (P).

Letter, Betzler to OUP, 3 Jul 1958. UWH box 53, PMH224; letter, Agar-Hamilton to Betzler, 8 Mar 1960. UWH box 27, PMH107/A/1a. DDS (P). 
General G.E. Brink, sought a stay of execution through 1959-60, without avail. ${ }^{38}$ An extension to July 1961 in order to see War in the Southern Oceans through to publication was agreed, but nothing more.

Representations to the prime minister, Dr Hendrik Verwoerd, produced bland assurances that the archive of documents and completed narratives would be made available to 'historians and research workers in the usual manner, subject to the provisions of the Archives Act 1953', but as severd friends of the official history pointed out, this legislation operated a fifty-year closure rule in common with archive acts elsewhere in the Commonwealth. ${ }^{39}$ The Secretary to the Prime Minister, J.P.V. Visser, claimed that it was "never intended that a complete and authoritative history of the military operations of the Union Defence Force . . . should be written', which was not true; that in other Commonwealth countries there was no intention 'to set up permanent organizations for the purpose of completing their war histories', which was only partly true; and that the decision of the government to dissolve the Union War Histories section 'does not mean, however, that the compilation of the Union War Histories has now come to an end', which was patently absurd. ${ }^{40}$ Brink's suggestion that others be allowed to step in to save the program was met with an assurance that consideration would be given to 'the most effective manner whereby historians should be encouraged and assisted to work on the data [sic]' but with the proviso that 'steps will, however, have to be taken to guard against any arrangement which will result in waste of time as well as economic loss to the State'. ${ }^{41}$ The worth of these assurances was demonstrated in 1961 when the Commandant General of the South African Defence Force, General P.H. Grobbelaar, attempted to persuade the government to transfer the materials to his charge and authorize the Military History Section within Defence Headquarters to continue and finish the series; he was rebuffed. $^{42}$

Agar-Hamilton had intended to publish at least four more volumes in the official history: the campaign in East Africa; the involvement of the $6^{\text {th }}$ South African Armoured Division in the Italian campaign; a history of the South African Air Force; and what was known as the 'gap' history, covering the Western Desert

See, for example, letter, Betzler to Colonel A.C. Martin, Durban 2 Dec 1959. UWH box 7, PMH37 volume 2; letter, Agar-Hamilton to Betzler, 15 Jun 1960. UWH box 27. PMH107/A/1a: letter, Joan North to L.C.F. Turner, 4 Dec 1960. UWH box 28 , PMH107/A/13a. DDS (P).

Hansard, 20, 12 Jun 1962, 7622.

Letter, Visser to Brink, 8 Oct 1959. MU/EF box 100, MU41. DDS (P).

Letter, Visser to Brink, 14 Dec 1959, cited in letter, Secretary, South African ExServices National Council to Adjutant General, 2 Apr 1963. KG5 box 31, KG/AOH/4. DDS (P).

Minute, Commandant General to Minister for Defence, 11 Aug 1961. Ibid. The records amassed by UWH were later transferred to Defence Headquarters, but the continuation of the series under official auspices was refused. 
from Sidi Rezeg to the fall of Tobruk. The narratives for these were largely completed, and in addition to the records of South African, Commonwealth and other allied units and formations the section had amassed a large collection of German and Italian documents, many translated by Betzler. The whole came to more than 25000 files and two and a half thousand volumes, together with periodicals, newspapers, photographs and maps. In the end another nine volumes were published commercially in the 1970 s to fill out the coverage of South Africa's war, but these volumes were neither as rigorous, as sophisticated nor as authoritative as the three books produced by Union War Histories. ${ }^{43}$

Agar-Hamilton, Turner and the rest are long dead and forgotten, their work hardly known outside South Africa and, I suspect, rarely read within it. (In his famous 1971 survey of official histories around the world, the American scholar Robin Higham provided no listing for the South African histories at all, so thoroughly had South Africa's effort dropped from outside view.) The Union War Histories section was a victim of the communal politics of white South Africa, as Agar-Hamilton had foreseen it might become in 1944. He was an astute and able historian and administrator, but he relied politically on the association with Smuts, and when this no longer afforded protection he had few other resources on which to draw. The section was a little island of 'Englishness' at a time when Afrikaner nationalism was asserting itself in a more radical manner and with access to the levers of state power. Agar-Hamilton himself was a known opponent of that process and he openly identified himself with others, like Fouche, who were similarly tainted in Nationalist eyes. South African involvement in the Second World War had provoked intense hostility, bitterness and division among many Afrikaners and the official histories, in their own small way, were a reminder of that fact and that period for Nationalist politicians who were inclined neither to forgive nor forget once they had come to power at last. Criticism of leading wartime officers like Pienaar and Klopper, however well deserved, would have done nothing to endear the historians to their new political masters. Although it was considered at one point, the histories were not translated into Afrikaans. ${ }^{44}$

Responding to news of the closure of the section, the Editor-in-Chief of the New Zealand official history, Brigadier M.C. Fairbrother, wrote that 'the two highquality volumes so far published deal with the Union's disasters during the war, but the successes apparently must go unrecorded ... We New Zealanders ... know well the quality of the effort made in those days ... A nation loses some of its treasures in not making such a record permanent'. ${ }^{5}$ Agar-Hamilton and Turner were part of a small but very active international community of English-speaking scholars

Van der Waag, Marriage of Clio and Mars, p 84.

Minutes, Union War Histories Advisory Committee, 3 Apr 1951. UWH box 10, PMH51/A. DDS (P).

Letter, Fairbrother to Mrs J.W. North, 8 Sep 1960. UWH box 27, PMH107/A/3. DDS (P). 
attempting in the 1940s and 1950s to document and make sense of the world's greatest conflict and of their nations' roles in the defeat of the Axis powers. Their contribution to an understanding of one part of that conflict in particular, the campaign in North Africa, was widely and warmly regarded elsewhere and set standards of scholarship in the field. The decision to shut down that effort and leave the series incomplete was a small foretaste of the closing of the South African mind and the isolation of South African scholarship that was to intensify in succeeding decades. 